\title{
Isolation of Extremely Thermophilic Sulfate Reducers: Evidence for a Novel Branch of Archaebacteria
}

Karl O. Stetter, Gerta Lauerer, Michael Thomm, and Annemarie Neuner 


\section{Isolation of Extremely Thermophilic Sulfate Reducers: Evidence for a Novel Branch of Archaebacteria}

\section{Karl O. Stetter, Gerta lauerer, Michael Thomm, ANNEMARIE NEUNER}

Extremely thermophilic archaebacteria are known to be metabolizers of elemental sulfur and the methanogens. A novel group of extremely thermophilic archaebacteria is described, which consists of sulfate-respiring organisms that contain pure factor 420 and that have been isolated from marine hydrothermal systems in Italy. They possess a third type of archaebacterial RNA polymerase structure previously unknown, indicating an exceptional phylogenetic position. Most likely, this group represents a third major branch within the archaebacteria. The existence of sulfate reducers at extremely high temperatures could explain hydrogen sulfide formation in hot sulfate-containing environments, such as submarine hydrothermal systems and deep oil wells.

$\mathrm{T}$ WO MAIN SUBDIVISIONS OF ARchaebacteria are distinguished: one comprising the methanogenic bacteria and the extreme halophiles, and a second consisting of the sulfur-metabolizing extreme thermophiles $(1)$. These branches can be recognized on the basis of a comparison of RNA polymerase structures (2), $16 S$ ribosomal RNA (rRNA) sequences (1), and metabolic properties. Members of the group of archaebacterial sulfur metabolizers are able to grow by either oxidizing or reducing elemental sulfur, depending on the genera $(3,4)$. Energy conservation by dissimilatory

Table 1. Substrates for growth of isolate VC-16. Portions of 20 - $\mathrm{ml}$ anaerobic sulfate- or thiosulfatecontaining mineral medium (MGG) (7) were supplemented with possible substrates ( 2 g/liter) and then inoculated (1\% inoculation) with strain VC-16. Incubation was usually at $85^{\circ}$ and $65^{\circ} \mathrm{C}$ in the case of glucose and pyruvate, respectively. Substrate utilization was determined after four transfers in sequence into the same culture medium ( $1 \%$ inoculation), each followed by an incubation period. Acids were added as sodium salts.

\begin{tabular}{ccc}
\hline & \multicolumn{2}{c}{ Class of nutrients } \\
\hline $\begin{array}{c}\text { Intermediates in } \\
\text { anaerobic degradation }\end{array}$ & Sugar & Complex substrates \\
\hline $\begin{array}{c}\text { Molecular hydrogen, * formate, } \\
\text { formamide, } \mathrm{L}(+) \text { - and } \\
\mathrm{D}(-) \text {-lactate, pyruvate }\end{array}$ & Glucose & $\begin{array}{c}\text { Yeast extract, casamino acids, * beef extract, peptone, } \\
\text { cell homogenates of } E \text {. coli, Lactobacillus bavaricus } \\
\text { and Methanothermus fervidus }\end{array}$ \\
\hline
\end{tabular}

*Growth only in thiosulfate-containing medium.

sulfate reduction has been observed up to now exclusively within some eubacteria (5). Eubacterial sulfate reducers are mesophiles or moderate thermophiles and play an important role in the global sulfur cycle (5). We describe here a novel group of extremely thermophilic sulfate reducers that belong to the archaebacterial kingdom.

To study microbial life at extremely high temperatures, we collected 45 anaerobic samples (6) of hot sediments from marine hydrothermal systems in the vicinities of Vulcano and Stufe di Nerone, Italy. The original temperatures of the sediments ranged between $70^{\circ}$ and $100^{\circ} \mathrm{C}$. In the laboratory, oxygen-free marine mineral medium supplemented with $0.1 \%(\mathrm{w} / \mathrm{v})$ yeast extract (Difco) was inoculated with portions of each sample $(7,8)$ and then incubated at $85^{\circ} \mathrm{C}$ (gas phase: $\mathrm{N}_{2} / \mathrm{CO}_{2}=80 / 20$ ). After 1 week we observed coccoid bacterial cells in 28 of the 45 cultures that we attempted to form. They showed a strong blue-green fluorescence under the ultraviolet (UV) $\mathrm{mi}$ croscope at $420 \mathrm{~nm}$ characteristic of methanogenic bacteria $(8)$.

Surprisingly, however, only traces of methane (about $10^{-4}$ times that produced by a methanogen culture of comparable cell density) were detected. The novel organisms were cloned by plating on culture medium solidified by $1.5 \%$ agar (Oxoid). The plates were incubated anaerobically at $70^{\circ} \mathrm{C}(8)$. Isolate $\mathrm{VC}-16$ from Vulcano was the first

Institut für Biochemie, Genetik und Mikrobiologie, Universität Regensburg, Universitätsstraße 31, D-8400 Re gensburg, Federal Republic of Germany.

SCIENCE, VOL. 236 

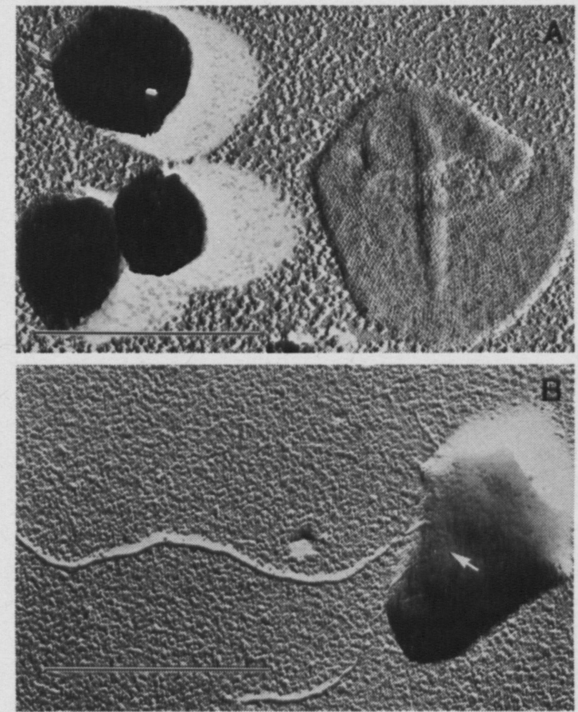

Fig. 1. Electron micrographs of isolate VC-16, platinum-shadowed. (A) Cells and empty envelope, (B) cell with two flagella protruding from a single origin (arrow). Scale bars, $1 \mu \mathrm{m}$.

strain obtained in pure culture and was therefore studied in detail.

Cultures of VC-16 consisted of irregular spherical cells with envelopes composed of subunits in hexagonal array (Fig. 1A). The cells were motile and possessed flagella protruding from a common location (Fig. 1B, arrow). The new organisms grew within a temperature range between $64^{\circ}$ and $92^{\circ} \mathrm{C}$, with an optimum at approximately $83^{\circ} \mathrm{C}$ (corresponding to a doubling time of about 4 hours). Growth depended on the presence of sulfate, which was supplied in the culture medium $(14 \mu \mathrm{mol} / \mathrm{ml})$. Large amounts of $\mathrm{H}_{2} \mathrm{~S}$ (up to $6 \mu \mathrm{mol} / \mathrm{ml}$ ) and $\mathrm{CO}_{2}$ were formed during growth, indicating that the new organisms carried out dissimilatory sulfate reduction (5). In addition, methane (up to $0.01 \mu \mathrm{mol} / \mathrm{ml}$ ) was formed. Sulfate could be replaced by thiosulfate $(14 \mu \mathrm{mol} / \mathrm{ml})$ and by sulfite $(1 \mu \mathrm{mol} / \mathrm{ml})$, but not by elemental sulfur. Molecular hydrogen and some simple organic molecules served as substrates (Table 1). In contrast to eubacterial sulfate reducers (5), complex organic substrates and even glucose were used (Table 1). As expected, crude oil (Höhenrain; Preussag, Hannover) did not support growth. However, it was not inhibitory when present with substrates. This finding suggests that the new organisms could be responsible for the formation of $\mathrm{H}_{2} \mathrm{~S}$ in geothermally heated oil wells ("sour oil") when suitable substrates and sulfate-containing water are present. In batch culture with $\mathrm{L}(+)$-lactate as the substrate, 140-g cells (wet weight) were obtained in a 300-liter, enamel-protected fermentor (Pfaudler, West Germany).

The isolate VC-16 was recognized as an archaebacterium on the basis of (i) its 165
rRNA sequence $(1,9)$, (ii) the existence of an adenosine diphosphate-ribosylable protein in the rrude extract $(10,11)$, (iii) the presence of phytanyl ether lipids $(12,13)$, (iv) a cell wall consisting of glycoprotein instead of murein (14), and (v) the presence of an RNA polymerase with eight subunits resistant to $200 \mu \mathrm{g} / \mathrm{ml}$ of rifampicin and streptolydigin (2). DNA from isolate VC16 had a content of guanosine plus cytosine of $46 \mathrm{~mol} \%(4,15)$. Spectra of the enriched compound that fluoresced blue-green in the UV light showed the same excitation and emission maxima (419 and $467.5 \mathrm{~nm}$, respectively) as pure factor $420\left(\mathrm{~F}_{420}\right)$ from Methanobacterium thermoautotrophicum and as enriched $\mathrm{F}_{420}$ from Methanococcus thermolithotrophicus (Fig. 2) (16). This finding suggests that the unknown compound was an 8-OH-5-deazaflavin similar to $\mathrm{F}_{420}$ in methanogenic bacteria (17). Cell extracts of VC16 also contained substances showing the same ultraviolet/visual spectrophotometry spectrum as methanopterin and 5,10-methenyltetrahydro methanopterin $(18,19)$. In contrast to methanogens, no substance showing the spectrum of factor $430\left(\mathrm{~F}_{430}\right)$ (18) could be detected. Moreover, coenzyme M (2-mercaptoethanesulfonic acid) as determined by the bioassay described by Balch and Wolfe $(20)$ was not evident. The formation of methane without coenzyme $\mathrm{M}$ and $\mathrm{F}_{430}$ could be analogous to the "mini methane production" described for some eubacteria (21). The essential enzymes of the dissimilatory sulfate reduction pathway, namely, adenosine triphosphate sulfurylase, adenylyl-sulfate reductase, and bisulfite re-

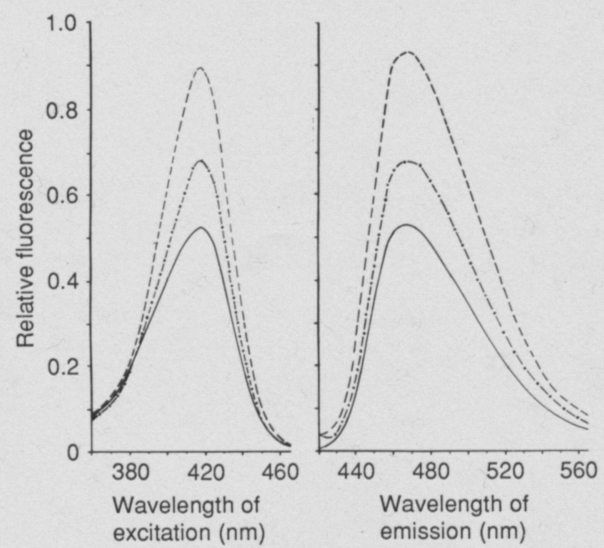

Fig. 2. Excitation and emission spectra of the fluorescent compound of the new isolate VC-16 $(--)$ and of $\mathrm{F}_{420}$ from M. thermolithotrophicus (--), and $M$. thermoautotrophicum (-). The fluorescent compound of isolate VC-16 and $\mathrm{F}_{420}$ from $M$. thermolithotrophicus was extracted from the cells with acetone and was purified by chromatography on a QAE-Sephadex A 25 column (16). The excitation and emission spectra were measured in a Cary $118 \mathrm{C}$ spectrophotometer and a Hitachi-Perkin'Elmer fluorescence spectrophotometer MPF-44 A, respectively (buffer: $50 \mathrm{mM}$ tris, $p \mathrm{H} \mathrm{7.5}$, and $\mathrm{l} M \mathrm{NaCl}$ ).

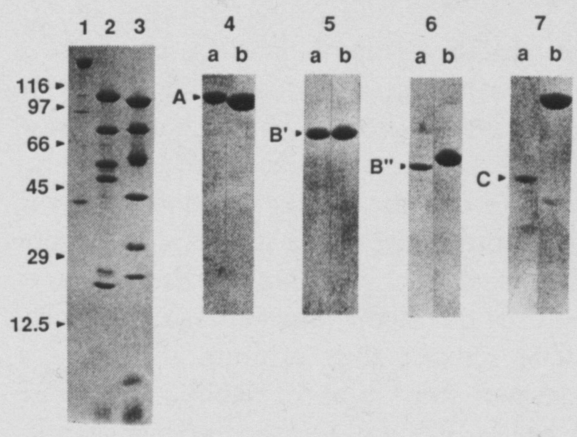

Fig. 3. SDS-polyacrylamide gel electrophoresis and immunochallenging (Western blots) of DNA-dependent RNA polymerases. RNA polymerases of 1, Escherichia coli; 2 and 4 a to $7 \mathrm{a}, M$. thermolithotrophicus; 3 and $4 \mathrm{~b}$ to $7 \mathrm{~b}$, isolate VC16. Coomassie staining of 1 to 3 . The positions of molecular weight standards in the polyacrylamide gel are on the left side. Escherichia coli RNA polymerase was obtained from Boehringer Mannheim. RNA polymerases of $M$. thermolithotrophicus and VC-16 were purified by standard methods (23). Western blots of components of RNA polymerases of $M$. thermolithotrophicus and of isolate VC-16 were challenged $(2,26)$ with antibodies directed against single components $\mathrm{A}, \mathrm{B}^{\prime}, \mathrm{B}^{\prime \prime}$, and $\mathrm{C}$ (lanes 4 to 7 , respectively) of the RNA polymerase of $M$. thermoautotrophicum (2). Bound antibodies were visualized with peroxidase-coupled antibodies to immunoglobulin G.

ductase exist in cell extracts of VC-16 and are under investigation (22).

The phylogenetic position of the newly isolated sulfate reducers within the archaebacteria was investigated by comparing DNA-dependent RNA polymerases. Within archaebacteria, only two distinct types of RNA polymerase structures are known that parallel the two phylogenetic branches: the BAC-type of the $S^{\circ}$-metabolizing and the $\mathrm{AB}^{\prime} \mathrm{B}^{\prime \prime} \mathrm{C}$-type of the methanogenic-halophilic archaebacteria. The basis of this difference is the occurrence of two polypeptides, $\mathrm{B}^{\prime}$ and $\mathrm{B}^{\prime \prime}$, in the $\mathrm{AB}^{\prime} \mathrm{B}^{\prime \prime} \mathrm{C}$-type, which show homology to component $\mathrm{B}$ of the other type $(2,23)$. The RNA polymerase purified from VC-16 exhibited eight identifiable components, each having a different molecular weight (Fig. 3, lane 3). Structural homologies between the RNA polymerases of the novel sulfate reducer and other archaebacteria were revealed by immunological crossreactions. Antibodies directed against the single components of $M$. thermoautotrophicum RNA polymerase were challenged with isolated components of the enzymes of VC16 (Fig. 3, lanes $4 \mathrm{~b}$ to $7 \mathrm{~b}$ ) and, as a control, of M. thermolithotrophicus (Fig. 3, lanes 4a to 7a). The three heaviest components of the VC-16 enzyme showed serological crossreaction with components $\mathrm{A}, \mathrm{B}^{\prime}$, and $\mathrm{B}^{\prime \prime}$ of the methanogen enzyme, so far indicating homology to the $\mathrm{AB}^{\prime} \mathrm{B}^{\prime \prime} \mathrm{C}$ structure. Antibodies directed against the fourth largest component $(\mathrm{C})$ of the enzyme of methano- 
genic bacteria (Fig. 3, lane 7a) exhibited a strong cross-reaction with the heaviest component (A) of the VC-16 RNA polymerase (Fig. 3, lane 7b). This cross-reaction demonstrates that the largest component of the RNA polymerase of the sulfate reducer contained structural elements of components $A$ and $C$ of the methanogen enzyme. The new sulfate reducer thus exhibits a previously unknown third type of RNA polymerase $(A+C) B^{\prime} B^{\prime \prime}$ within the archaebacteria, which is phylogenetically removed from those of the two accepted archaebacterial branches. This finding provides evidence for the existence of a third phylogenetic branch within the archaebacterial kingdom.

On the basis of their phylogenetic uniqueness, archaebacterial sulfate reducers may have existed since ancient times. Early Archaean ocean waters were generally poor in sulfate and were thus unfavorable for the presence of sulfate reducers that were thought to have originated later (24). This theory is in line with the lack of significant biogenic sulfur isotope fractionation within such sediments (24). However, there should have been reasonable quantities of sulfate of magmatic origin present locally within Archaean hydrothermal systems (25). Therefore, sulfate reduction by extremely thermophilic archaebacteria could have existed since early Archaean times and may be an ancient type of metabolism.

\section{REFERENCES AND NOTES}

1. C. R. Woese and G. J. Olsen, Syst. Appl. Microbiol. 7 , 161 (1986).

2. W. Zillig, K. O. Stetter, R. Schnabel, M. Thomm, in The Bacteria, C. R. Woese and R. S. Wolfe, Eds. (Academic Press, Orlando, FL, 1985), vol. 8, pp 499-524.

3. T. D. Brock, K. M. Brock, R. T. Belly, R. L. Weiss, Arch. Microbiol. 84, 54 (1972)

4. A. Segerer, K. O. Stetter, F. Klink, Nature (London) 313, 787 (1985).

5. F. Widdel, in Anaerobic Bacteria in Habitats Other Than Men, E. M. Barnes and G. C. Mead, Eds. (Blackwell, Oxford, 1986), pp. 157-184

6. K. O. Stetter, Nature (London) 300, 258 (1982).

7. H. Huber, M. Thomm, H. König, G. Thies, K. O Stetter, Arch. Microbiol. 132, 47 (1982).

8. W. E. Balch, G. E. Fox, L. J. Magrum, C. R. Woese, R. S. Wolfe, Microbiol. Rev. 43, 260 (1979)

9. C. R. Woese, personal communication.

10. M. Kessel and F. Klink, Nature (London) 287, 250 (1980)

11. F. Klink, personal communication.

12. T. A. Langworthy, T. G. Tornabene, G. Holzer,
Zentralbl. Bakteriol. Mikrobiol. Hyg. 1 Abt. Orig. C 3, 228 (1982).

13. T. A. Langworthy, personal communication.

14. H. König, personal communication.

15. J. Marmur and P. Doty, J. Mol. Biol. 5, 109 (1962).

16. P. Schönheit, H. Keweloh, R. K. Thauer, FEMS (Fed. Eur. Microbiol. Soc.) Microbiol. Lett. 12, 347 (1981).

17. P. Cheeseman, A. Toms-Woods, R. S. Wolfe, J. Bacteriol. 112, 527 (1972).

18. A. Pfaltz, personal communication

19. J. T. Keltiens, M. J. Huberts, W. H. Laarhoven, G D. Vogels, Eur. J. Biochem. 130, 537 (1983).

20. W. E. Balch and R. S. Wolfe, J. Bacteriol. 137, 256 (1979).

21. R. Schauder, B. Eikmanns, R. K. Thauer, F. Widdel, G. Fuchs, Arch. Microbiol. 145, 162 (1986).

22. H. G. Trüper, personal communication.

23. M. Thomm, J. Madon, K. O. Stetter, Biol. Chem. Hoppe-Seyler 367, 473 (1986).

24. E. M. Cameron, Nature (London) 296, 145 (1982).

25. K. Hattori and E. M. Cameron, ibid. 319, 45 (1986).

26. H. Towbin, T. Staehelin J. Gordon, Proc. Natl. Acad. Sci. U.S.A. 76, 4350 (1979).

27. We thank F. Klink, H. König, T. A. Langworthy, A Pfalz, H. G. Trüper, and C. R. Woese for communicating unpublished results; $R$. Thauer for the gift of $F_{420}$ and for discussions; $R$. Jaenicke for spectroscopy; N. Pfennig, D. Ubben, and P. Ziegler for discussions; and $\mathrm{W}$. Kleinitz for oil samples. Sup ported by grants from the Deutsche Forschungsgemeinschaft (SFB 43 and Schwerpunkt: Methanogene Bakterien) and the Fonds der Chemischen Industrie to K.O.S

1 December 1986; accepted 20 February 1987 